\title{
The role of juvenile Dermacentor reticulatus ticks as vectors of microorganisms and the problem of 'meal contamination'
}

\author{
Dorota Dwużnik ${ }^{1}$ Ewa J. Mierzejewska ${ }^{1} \cdot$ Paulina Drabik ${ }^{1} \cdot$ Agnieszka Kloch $^{2}$. \\ Mohammed Alsarraf ${ }^{1}$. Jerzy M. Behnke ${ }^{3}$. Anna Bajer ${ }^{1}$ (D)
}

Received: 4 February 2019 / Accepted: 13 May 2019 / Published online: 22 May 2019

(c) The Author(s) 2019

\begin{abstract}
Juvenile Dermacentor reticulatus ticks inhabit nests and burrows of their rodent hosts and cannot be collected from vegetation. To detect vertical transmission of Babesia canis in $D$. reticulatus, we studied larvae and nymphs collected from rodents. However, the molecular techniques used for detection of pathogen DNA are sensitive enough to detect not only pathogens vectored by ticks but also those taken up with current or previous blood meals ('meal contamination') or just present in the environment and on the tick or host surface ('environmental contaminations'). Thus, an additional aim of our study was to evaluate the extent of such contamination while studying feeding ticks collected from rodents. Juvenile $D$. reticulatus were collected from 140 rodents: 91 bank voles trapped in two forest sites in the Mazury Lake District and 49 rodents (Apodemus and Microtus spp.) from an open habitat near the town of Białobrzegi in Central Poland. Altogether 504 D. reticulatus ticks, comprising 266 individually evaluated nymphs and 238 larvae assigned to 50 larval pools, were studied for the presence of Babesia, Bartonella and Rickettsia spp. DNA. Statistical analyses were conducted to (1) evaluate the effect of rodent host factors (species, sex and age) on prevalence of infection in ticks, and (2) to compare the frequency of positive samples between groups of pathogen-positive and pathogen-negative rodent hosts. To complete the last aim, blood samples obtained from 49 rodents from Białobrzegi were studied for the presence of Babesia and Bartonella DNA. Infestation of rodent hosts with juvenile ticks ranged between 46 and $78 \%$, with a mean abundance of 3.6 ticks/rodent for $D$. reticulatus and 4.8 ticks/rodent for Ixodes ricinus. The highest prevalence of PCR-positive $D$. reticulatus samples was obtained for Rickettsia spp. (28\%) and $R$. raoultii was identified in 22 sequenced PCR products. Babesia DNA was detected in 20 (7.5\%), including $B$. microti in $18(6.8 \%)$ and B. canis in two $(0.8 \%)$ of 266 D. reticulatus nymphs that were analyzed. Babesia microti DNA was also detected in four pools of $D$. reticulatus larvae $(4 / 50$ pools $=8 \%$ ). The detection success of $B$. microti in $D$. reticulatus was associated with the species of the rodent hosts of the ticks (much higher for typical $B$. microti-host-species such as Microtus spp. than for Apodemus spp.) and host age $(3 \times$ higher in ticks collected from adult hosts in comparison to juvenile ones). Moreover, the DNA of B. microti was detected in $68 \%$ of $D$. reticulatus nymphs collected from $B$. microti-positive rodents in comparison to only $1.6 \%$ of nymphs collected from B. microti-negative rodents. Bartonella DNA was
\end{abstract}

Anna Bajer

anabena@biol.uw.edu.pl

Extended author information available on the last page of the article 
detected in $18 \%$ of $D$. reticulatus tick samples (38\% of larval pools, $14 \%$ of nymphs). Again, host factors played important roles for 'tick positivity'-the highest prevalence of positive ticks was on Apodemus spp., which are regarded as Bartonella reservoirs. Bartonella DNA was detected in $42 \%$ of nymphs and $57 \%$ of larval pools collected from Bartonella-positive rodents in comparison to $28 \%$ of nymphs and $11 \%$ of larvae collected from Bartonella-negative rodents. Vertical transmission of B. canis in D. reticulatus ticks was confirmed in the field. Additionally, we demonstrated that 'meal contamination' generates a confounding signal in molecular detection of pathogen DNA extracted from ticks collected from infected hosts and must be taken into account in evaluating the competence of tick species as vectors.

\section{Keywords Dermacentor reticulatus $\cdot$ Babesia canis $\cdot$ Babesia microti $\cdot$ Bartonella $\cdot$} Rickettsia raoultii $\cdot$ Vertical transmission $\cdot$ Rodents

\section{Introduction}

Vertical transmission (transovarial or transstadial) is known to play a crucial role in the maintenance of tick-borne pathogens in tick populations. To confirm transovarial transmission, naïve (unfed) or questing larvae of certain tick species need to be examined for the presence of relevant pathogens. Similarly, for transstadial transmission questing and as yet unfed nymphs should be the focus of investigation. Collection of questing instars from vegetation and the environment is relatively easy for exophilic tick species, i.e. Ixodes ricinus, however cannot be accomplished for endophilic tick species. In the case of Dermacentor reticulatus juvenile ticks inhabit nests and burrows of their rodent hosts from which they do not emerge and hence cannot be collected from vegetation (Rubel et al. 2016).

The ornate dog tick, D. reticulatus, is widely regarded as the main vector of Babesia canis (Rar et al. 2005a; Mierzejewska et al. 2015a; Rubel et al. 2016). The recent spread of this tick species in many European countries (Matjila et al. 2005; Schaarschmidt et al. 2013; Földvári et al. 2016; Mierzejewska et al. 2016) has resulted in the contemporaneous spread of canine babesiosis and has raised questions about the possible zoonotic reservoir of $B$. canis and the possibility of vertical transmission of the piroplasm in the tick population. To investigate the possibility of vertical transmission of $B$. canis in D. reticulatus under natural conditions, we studied larvae and nymphs collected from rodents since freeranging juveniles are not available on vegetation.

Ticks collected from hosts usually present a range of engorgement levels (Mierzejewska et al. 2015b), however even recently attached specimens which are still identical in morphological indices and weight with questing co-mates, should not be treated as totally naïve and unfed. Feeding ticks are in contact with a range of host tissue: blood, skin, connective tissue. Molecular techniques used for the detection of pathogen DNA in ticks are sensitive enough to detect pathogens present in host tissues in addition to these vectored or hosted by ticks (Egyed and Makrai 2014). Moreover, some studies have reported detection of host and pathogen DNA from previous blood meals, completed in earlier stages of tick life (Pichon et al. 2003; Wodecka and Skotarczak 2016). In summary, applying PCR-based sensitive techniques for the detection of pathogen DNA in feeding ticks may result in the detection of 'meal contamination' in cases of ticks feeding or having fed on infected hosts or in the detection of microorganisms present in the environment and contaminating tick or host surfaces. Thus, an additional aim of our study was to evaluate the extent of such contamination while studying feeding ticks collected from rodents, which are often naturally 
infected with a range of vector-borne pathogens (Welc-Faleciak et al. 2008a, b; Paziewska et al. 2011; Bajer et al. 2014; Tolkacz et al. 2017).

To differentiate between 'meal contamination' and the presence of specific pathogens in ticks, we determined the infection status of rodent hosts with the corresponding pathogens and compared this with the detection of pathogen DNA in ticks from infected and non-infected hosts. Thus the aims of our study were: (1) to investigate the occurrence of vertical transmission of B. canis in D. reticulatus ticks under natural conditions; (2) to evaluate the vector role of juvenile $D$. reticulatus for other pathogens; (3) to evaluate the effect of rodent factors (host species, sex and age) on detection of pathogen DNA in tick samples; and (4) to compare the frequency of positive samples between groups of pathogen-positive and pathogen-negative rodents.

\section{Materials and methods}

\section{Field study}

Ticks were collected from rodents at four sites. Two sites, Urwitałt and Tałty, are located in the Mazury Lake District, in NE Poland. These two forest sites and the associated trapping procedures have been described in detail in our previous papers (Behnke et al. 2001, 2008a, b; Bajer et al. 2014). Ninety-one bank voles, Myodes glareolus, were trapped and inspected for ectoparasites from these two sites in August 2016 (Table 1).

Two additional sites, Białobrzegi (N 51.6587, E 20.9388) and Niewiadów (N 51.6237, E 19.9150), were selected in the expansion zone of D. reticulatus in the Mazovia region in Central Poland (Mierzejewska et al. 2016). These two sites comprised open habitats, fallow lands and abandoned meadows, and the rodent community at these sites consisted of typical open habitat species: several Microtus spp. voles and striped field mice Apodemus agrarius, with occasional visiting forest species $(A$. flavicollis, A. sylvaticus, M. glareolus) (Table 1). Urwitałt, Tałty and Białobrzegi are localized in areas endemic for $D$. reticulatus, as determined by the presence of adult ticks on vegetation (Mierzejewska et al. 2016). Niewiadów is located about $70 \mathrm{~km}$ to the West from Białobrzegi in an area historically free from D. reticulatus (Siuda 1993; Karbowiak 2009; Mierzejewska et al. 2016). This site was selected also to verify the actual range of $D$. reticulatus ticks in Poland.

Trappings of rodents was performed during the known period of activity of juvenile D. reticulatus in Poland (Karbowiak 2009). Rodents were trapped in June and August 2017 in Białobrzegi and Niewiadów, and in August 2016 in Urwitałt and Tałty (Table 1).

All procedures have been described in detail in our previous papers (Behnke et al. 2001, 2008a, b; Bajer et al. 2014). Briefly, rodents were live-trapped, transported to the laboratory in Urwitałt or processed at the trapping site, for trapping in the Mazury Lake District (Masuria) and in Mazovia, respectively. In Urwitałt rodents were inspected for ectoparasites after blood collection from the heart under terminal isoflurane anesthesia (Behnke et al. 2008a, b; Tołkacz et al. 2017). In Białobrzegi and Niewiadów rodents were inspected following non-terminal isoflurane anesthesia and released afterwards, as described previously (Tołkacz et al. 2017). Ectoparasites were collected into $70 \%$ ethanol. Blood smears were prepared from blood taken from the heart (Masuria) or tail tip (Mazovia). Additionally, blood samples were collected into 0.001 M EDTA for DNA extraction and molecular detection of pathogens in hosts. 


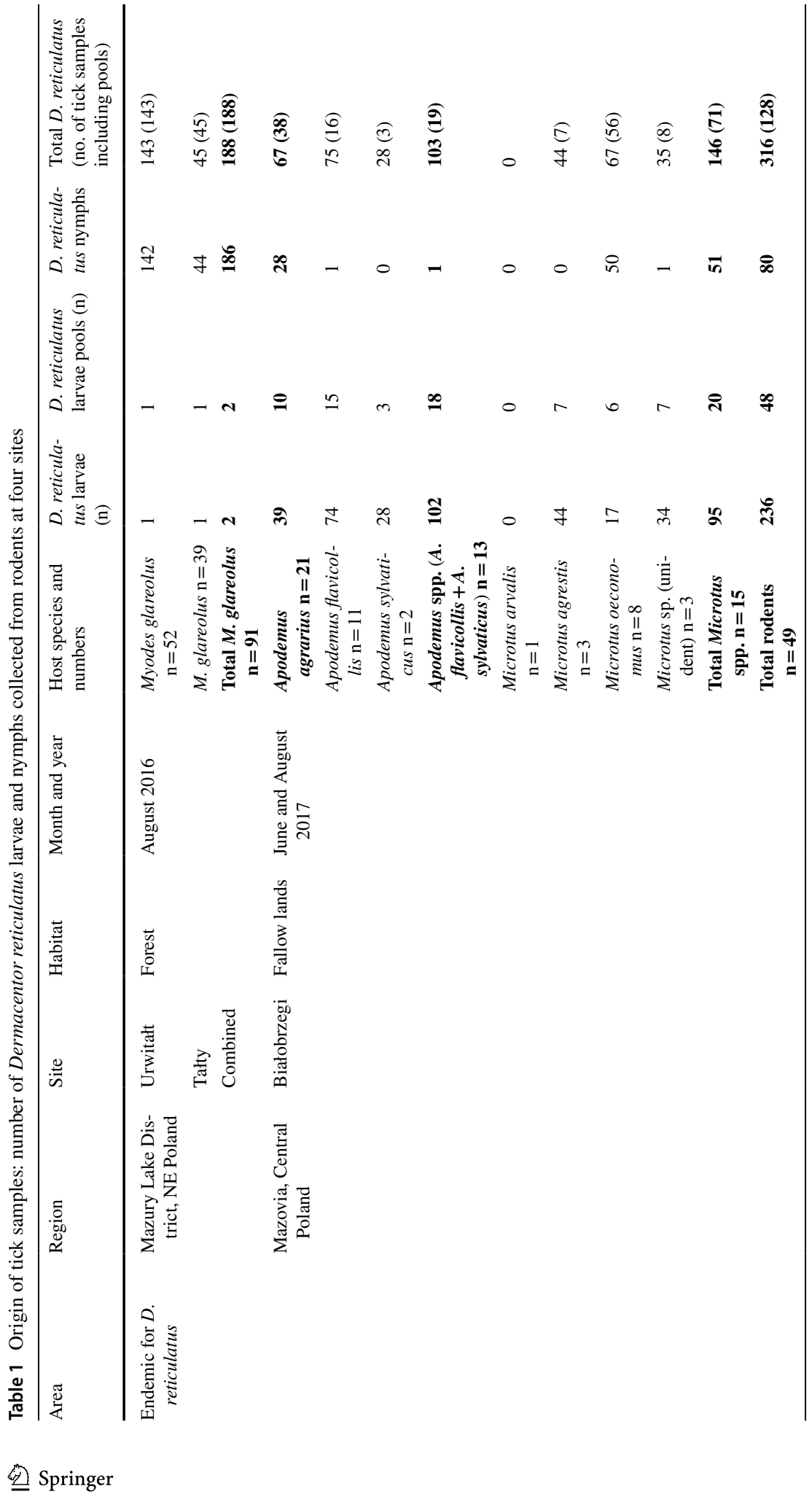




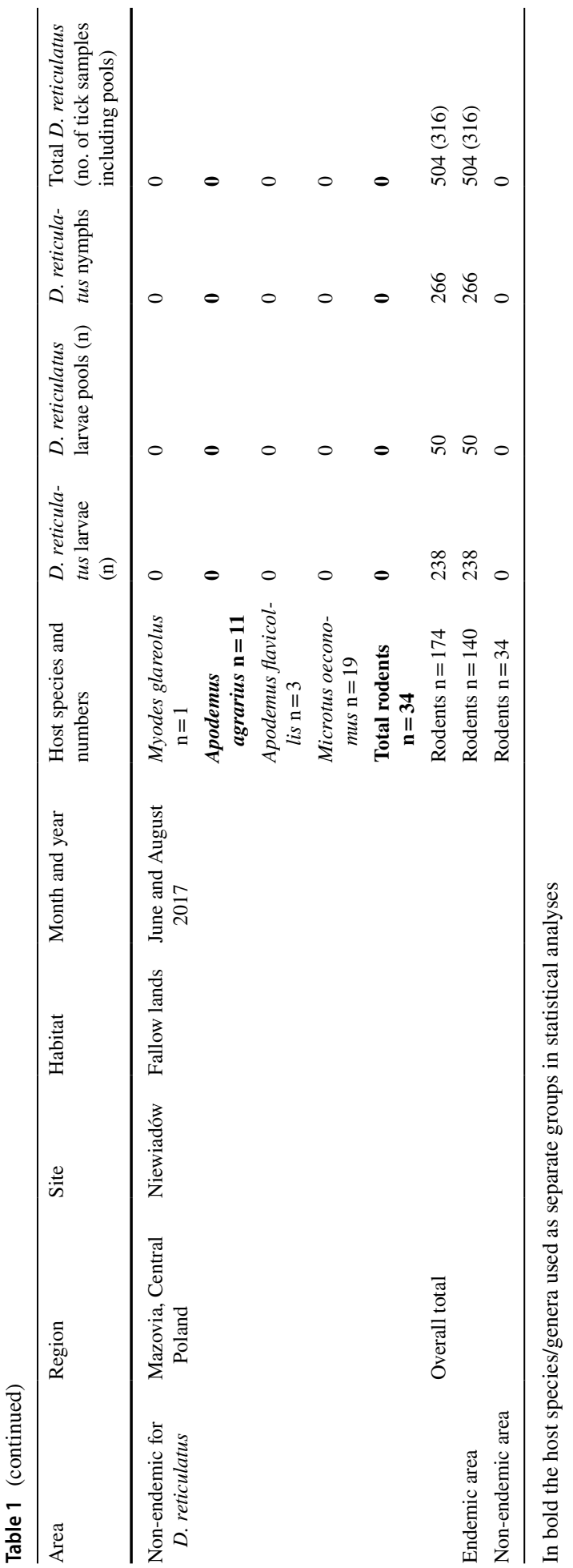




\section{Ethics approval}

All of the procedures were conducted with the approval of the First Warsaw Local Ethics Committee for Animal Experimentation in Poland (ethical license numbers: 304/2012 and 706/2015) according to the principles governing experimental conditions and care of laboratory animals required by the European Union and the Polish Law on Animal Protection.

\section{Tick identification}

Ticks were fixed in $70 \%$ ethanol, transported to the laboratory of the Department of Parasitology, Faculty of Biology, University of Warsaw and identified to species and stage level using a stereoscopic microscope equipped with a camera. All ticks were assigned to species and stages using the key of Estrada-Peña et al. (2004). Ticks were counted and two infestation parameters were calculated: prevalence (\% infested rodents) and abundance (mean number of ticks/individual).

\section{Tick processing}

Juvenile D. reticulatus, larvae and nymphs, were subjected to DNA extraction. Larvae were processed in pools, comprising 1-10 larvae from one host, as presented in Table 1. Nymphs were processed individually. Genomic DNA was extracted from ticks using Mini AX Tissue Spin DNA extraction kit (A\&A Biotechnology, Gdańsk, Poland).

\section{Detection of pathogen DNA by PCR}

PCR amplification was applied in the detection of Babesia, Bartonella and Rickettsia DNA in ticks. Additionally, blood samples from rodents from Białobrzegi and Niewiadów were examined for the presence of Babesia and Bartonella infection. DNA from these blood samples was extracted using Ultra Clean Blood Spin DNA Isolation Kit (MO BIO Laboratories, Qiagen, Carlsbad, CA, USA).

For the detection of Babesia spp., the 550 bp fragment of 18S rDNA was amplified in a nested PCR as described previously (Mierzejewska et al. 2015a). In the first reaction, primers CryptoF, CryptoR (Bonnet et al. 2007a, b) were used for amplification of a 1200 bp fragment; in the second step primers BabGF, BabGR (Bonnet et al. 2007a, b) were used for amplification of the $550 \mathrm{bp} 18 \mathrm{~S}$ rDNA.

For the detection of Bartonella spp., the $330 \mathrm{bp}$ gene fragment of rpoB was amplified in a nested PCR as described previously (Paziewska et al. 2011; Tołkacz et al. 2018). In the first reaction, primers $1400 \mathrm{~F}, 2300 \mathrm{R}$ were used for amplification of the $900 \mathrm{bp}$ rpoB fragment; in a second step primers rpoB F, rpoB R were used for amplification of the $330 \mathrm{bp}$ rpoB fragment.

For the detection of Rickettsia spp., the $750 \mathrm{bp}$ gltA gene fragment was amplified in a single-step PCR with primers CS409 and Rp1258 as described previously (Roux et al. 1997). 
Positive and negative controls were incorporated in each set of PCRs and selected PCR products obtained from tick samples and rodents were sequenced by a private company (Genomed, Warsaw, Poland).

\section{Sequence analysis}

DNA sequence alignments and analyses were conducted using MEGA v.7.0. Consensus sequences were compared with sequences deposited in the GenBank database (http://www. ncbi.nlm.nih.gov/genbank/).

\section{Statistical analyses}

Statistical analyses were conducted to: (1) evaluate the impact of host factors (rodent host species, sex and age) and study site on the detection of pathogen DNA in ticks collected from rodents, and (2) to associate the infection identified in tick samples with the infection status of the rodent hosts from which the ticks were collected.

For the first aim we analyzed the prevalence of pathogens (\% PCR-positive samples) in D. reticulatus tick samples. The statistical approach adopted has been documented comprehensively in our earlier publications (Behnke et al. 2001, 2008a, b). For analysis of prevalence we used maximum likelihood techniques based on log linear analysis of contingency tables in the software package SPSS (v.21, SPSS, Chicago, IL, USA). Initially, full factorial models were fitted, incorporating as factors rodent hosts of the ticks HOST SPECIES (four groups as explained below), SEX (two levels, males and females), AGE (two levels: juveniles and adults, based on breeding status) and SITE (4 levels, the four study sites). Four host species/genera were established for statistical analyses grouping open habitat species (group 1: A. agrarius; group 2: Microtus spp. [M. arvalis + M. agrestis $+M$. oeconomus + unidentified Microtus spp.]) and forest species separately (group 3: Apodemus spp. [A. flavicollis + A. sylvaticus]; group 4: M. glareolus). Prevalence of pathogens in ticks was considered as a binary factor (PRESENCE/ABSENCE of pathogen DNA in ticks). These explanatory factors were fitted initially to all models that were evaluated. For each level of analysis in turn, beginning with the most complex model, involving all possible main effects and interactions, those combinations that did not contribute significantly to explaining variation in the data were eliminated in a stepwise fashion beginning with the highest level interaction (backward selection procedure). A minimum sufficient model was then obtained, for which the likelihood ratio of $\chi^{2}$ was not significant, indicating that the model was sufficient in explaining the data (these values are given in the legends to the figures as relevant). The importance of each term (i.e. interactions involving infection) in the final model was assessed by the probability that its exclusion would alter the model significantly and these values relating to interactions that included PRESENCE/ABSENCE of pathogen DNA are given in the text.

For the second aim, additional analyses were performed, incorporating additional factor in the model: HOST INFECTION (PRESENCE/ABSENCE of pathogen in the rodent host of the tick), as determined by PCR. Two models were analyzed for B. microti and Bartonella spp.: HOST SPECIES $\times$ HOST INFECTION $\times$ TICK STADIUM $\times$ TICK INFECTION. In these analyses tick samples $(n=128)$ and rodents $(n=49)$ from Białobrzegi were used.

General linear models (GLMs in SPSS v.21) were used for comparison of mean tick abundance between sites. 


\section{Results}

\section{Tick infestation in rodents}

A total of 174 rodents were examined for ticks, including 92 M. glareolus, 32 A. agrarius, 14 A. flavicollis, two A. sylvaticus, 27 M. oeconomus, three M. agrestis, one M. arvalis and three juvenile Microtus voles (Microtus spp.) (Table 1), which could not be identified to species level because of their very small body size (juvenile $M$. agrestis and M. oeconomus voles are morphologically almost identical).

Altogether 1393 feeding ticks were collected from these rodents at four sites, including 504 D. reticulatus (238 larvae and 266 nymphs) and 889 I. ricinus (852 larvae and 37 nymphs). Ixodes ricinus was the most common species found on rodents at all sites (Fig. 1a). Total prevalence of this species on rodents ranged between 69 and 91\%, mainly due to the high infestation with I. ricinus larvae (Fig. 1a, NS). Mean abundance was also
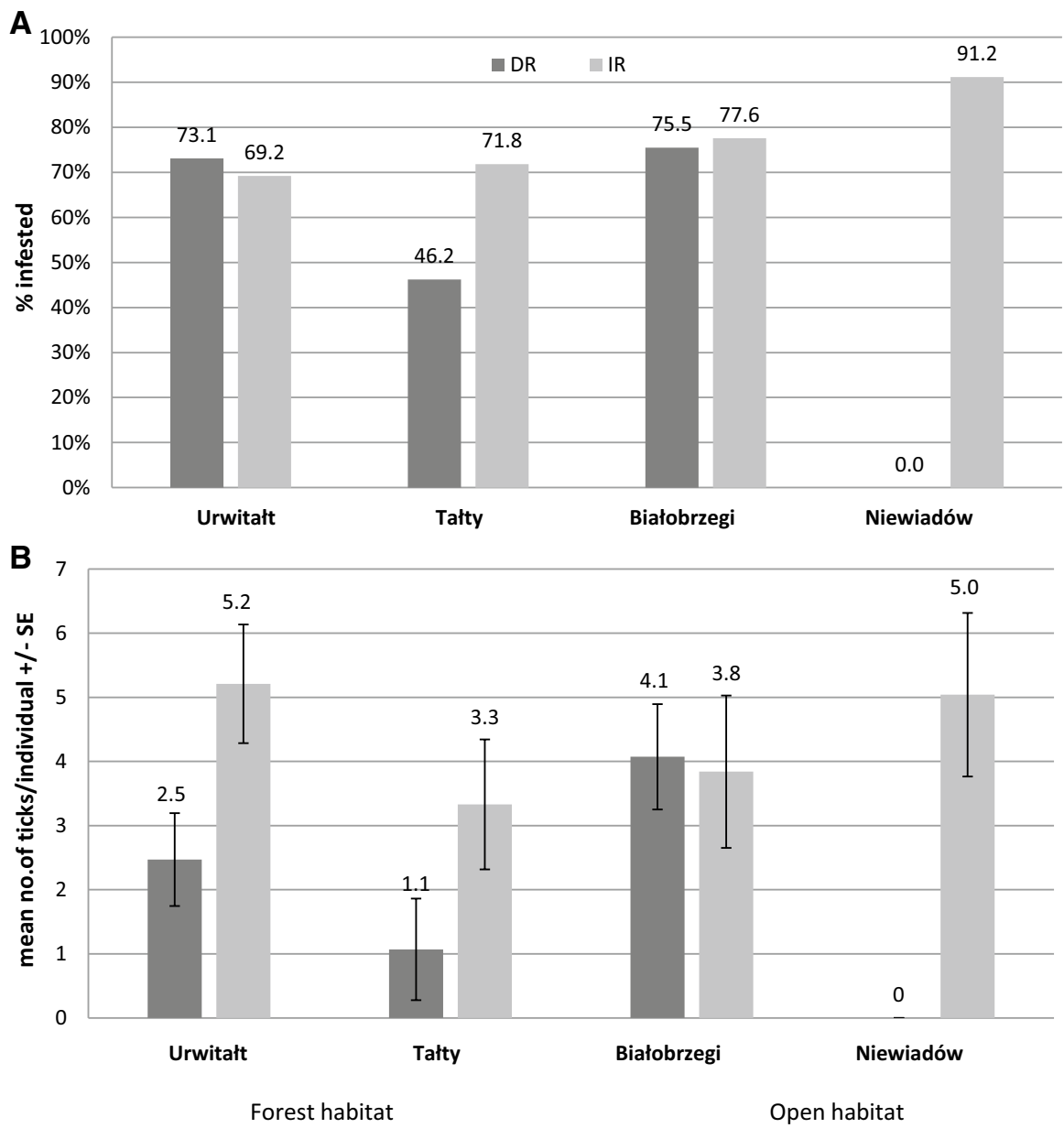

Fig. 1 Comparison of the prevalence of tick infestations (a) and abundance (b) on rodents from four trapping sites. DR D. reticulatus, IR I. ricinus 
similar between sites (Fig. 1b, NS). Juvenile D. reticulatus ticks were found on several species of rodents (Table 1) at three sites; no ticks of this species were recorded on rodents from Niewiadów (Fig. 1a, b; D. reticulatus PRESENCE/ABSENCE $\times$ SITE: $\chi_{3}^{2}=71.4$, $P<0.001$ ), supporting the hypothesis that this site is located outside the geographical range of $D$. reticulatus. Thus, rodents from this site were excluded from further analyses. The mean abundance of D. reticulatus ticks on rodents in tick endemic areas was 3.6 ticks/ host, a value that is similar to the mean abundance of juvenile I. ricinus (4.8 ticks/hosts). Mean abundance of $D$. reticulatus was highest on rodents caught in the open habitat in Białobrzegi and lowest at the forest site in Tałty (Fig. 1b; main effect of SITE on tick abundance: $\mathrm{F}_{3,173}=3.84, P=0.011$ ).

\section{Molecular detection of pathogen DNA in juvenile Dermacentor reticulatus and rodent hosts}

The overall frequencies (\% positive) of detection of specific pathogen DNA in larvae and nymphs of $D$. reticulatus are presented in Table 2 . The frequency of detection of pathogen DNA in $D$. reticulatus originating from different host species and from the three trapping sites where this tick species occurred is presented in Table 3, and it is clearly apparent that some host species dominated in each case. To enable comparison of infection of ticks and their rodent hosts, selected positive samples from ticks and rodents (Table 4) were sequenced and analyzed. Among the detected pathogens, Rickettsia was the most common and the rarest was Babesia spp.; a relatively high \% of Bartonella-positive samples were recorded among the pools of $D$. reticulatus larvae (Tables 2 and 3).

\section{Babesia spp.}

Altogether 42 PCR products of Babesia spp., including 24 samples from ticks (all positive; Table 2) and selected 18 samples from rodents (Table 4; 15 M. oeconomus, 2 A.agrarius, 1 A. flavicollis) were sequenced. Two Babesia species were identified: both B. microti and $B$. canis in ticks but only $B$. microti in rodents. All B. microti sequences from rodents and all but one sequence from ticks showed the closest similarity (99.6-100\%) to B. microti IRU1 genotype (KC470048). Only one $B$. microti sequence obtained from a $D$. reticulatus nymph from $A$. agrarius was identical with $B$. microti IRU2 genotype (KC470049). Two sequences obtained from the nymphs of $D$. reticulatus (one collected from M. glareolus from Urwitałt,

Table 2 Detection of pathogen DNA in larvae and nymphs of Dermacentor reticulatus from endemic areas

\begin{tabular}{|c|c|c|c|c|c|}
\hline \multicolumn{6}{|c|}{ Frequency ( $\%$ positive) of pathogen DNA detection } \\
\hline \multicolumn{6}{|c|}{$\begin{array}{lll}\text { No. of examined } & R \text {. raoultii } \\
\text { tick samples } & \mathrm{I} / \mathrm{N}\end{array}$} \\
\hline Larvae (pools) & 50 & $\begin{array}{l}21 / 50 \\
42.0 \%\end{array}$ & $\begin{array}{l}19 / 50 \\
38.0 \%\end{array}$ & $\begin{array}{l}4 / 50 \\
8.0 \%\end{array}$ & $\begin{array}{l}0 / 50 \\
0.0 \%\end{array}$ \\
\hline Nymphs & 266 & $\begin{array}{l}67 / 266 \\
25.2 \%\end{array}$ & $\begin{array}{l}38 / 266 \\
14.3 \%\end{array}$ & $\begin{array}{l}18 / 266 \\
6.8 \%\end{array}$ & $\begin{array}{l}2 / 266 \\
0.8 \%\end{array}$ \\
\hline Combined & 316 & $\begin{array}{l}88 / 316 \\
27.9 \%\end{array}$ & $\begin{array}{l}57 / 316 \\
18.0 \%\end{array}$ & $\begin{array}{l}22 / 316 \\
7.0 \%\end{array}$ & $\begin{array}{l}2 / 316 \\
0.6 \%\end{array}$ \\
\hline
\end{tabular}

$\mathrm{I}$-number of positive tick samples; $\mathrm{N}$-number of examined tick samples 


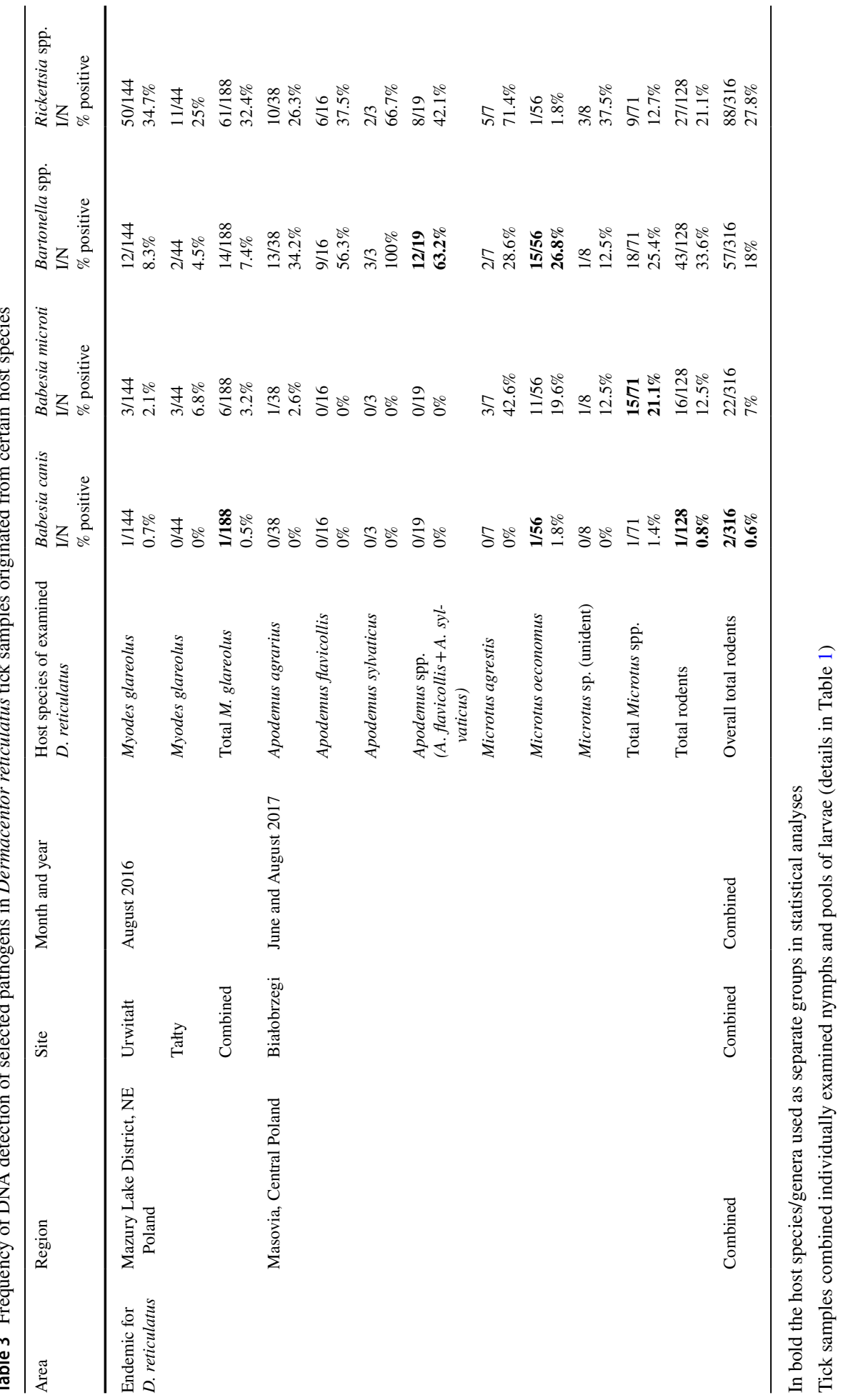


one from $M$. oeconomus from Białobrzegi) were essentially identical $(449 / 450=99.8 \%$ and $435 / 435=100 \%$ ) to the known sequence of $B$. canis (KY021189). Thus, the total frequency of Babesia DNA detection in juvenile D. reticulatus was $7.6 \%$, including $7 \%$ of tick samples positive for $B$. microti and two samples (0.6\%) positive for B. canis (Table 2). $B$. microti DNA was detected in eight rodents from Białobrzegi (16.3\%; Table 4). Host species had a significant effect on the prevalence of $B$. microti infection in rodents as reflected in the outcome of an analysis of presence/absence of $B$. microti in rodents from Białobrzegi (B. microti HOST INFECTION x HOST SPECIES: $\chi_{3}^{2}=19.5, P<0.001$ ). The highest prevalence of $B$. microti was identified in Microtus spp. (Table 4).

\section{Bartonella spp.}

Bartonella spp. DNA was detected in 57 juvenile D. reticulatus (18\%). Twenty-two PCR products were sequenced, including ten sequences from larval pools and 12 sequences from nymphs (Table 2). Three species/genotypes of Bartonella were identified; ten sequences displayed the highest similarity (99-100\%) to B. grahamii (KC633098); nine sequences were most similar to B. taylorii (99-100\%; MG839176) and three sequences were identical with the B. rochalimae-like isolate (MG839175). Bartonella DNA was detected in $38 \%$ of larval pools and in $14 \%$ of nymphs (Table 2).

Statistical analysis of Bartonella infections in ticks and rodents from Białobrzegi revealed a significant interaction between factors, including HOST SPECIES (Bartonella HOST INFECTION x HOST SPECIES x TICK STADIUM: $\left.\chi_{3}^{2}=11.7, P=0.008\right)$. Bartonella DNA was detected in 22 rodents from Białobrzegi (45\%; Table 4), with highest prevalence in mice, Apodemus spp. (84.6\%) but these infections in rodents were not isolated and sequenced.

\section{Rickettsia spp.}

Rickettsia DNA was detected in 88 D. reticulatus tick samples (28\%; Table 2). Twenty two PCR products were sequenced (nine from larval pools and 13 from nymphs). All sequences represented just one genotype, $100 \%$ identical with $R$. raoultii (KY474576). Rodent samples were not examined for Rickettsia.

\section{Host factors affecting frequency of DNA detection in ticks}

Rodent host species/genus (four groups as described in the "Materials and methods" section), host age and sex were fitted as factors influencing PRESENCE/ABSENCE of pathogen DNA in $D$. reticulatus ticks. The effect of these host factors on the frequency of pathogen detection in ticks is presented in Fig. 2a-c.

Host species/genus had a significant effect on the frequency of detection of three pathogens in D. reticulatus (Fig. 2a, Table 3). B. microti DNA was not detected in ticks collected from Apodemus spp. but the highest percentage of positive samples was recorded for ticks collected from Microtus spp. (B. microti PRESENCE/ABSENCE $\times$ HOST SPECIES: $\left.\chi_{3}^{2}=17.0, \mathrm{P}=0.001\right)$. The lowest frequency of samples positive for Bartonella spp. was recorded in ticks collected from $M$. glareolus and the highest in ticks collected from Apodemus spp. (Bartonella PRESENCE/ABSENCE $\times$ HOST SPECIES: $\chi_{3}^{2}=37.6$, $\mathrm{P}<0.001)$. The lowest frequency of samples positive for Rickettsia was recorded in ticks 


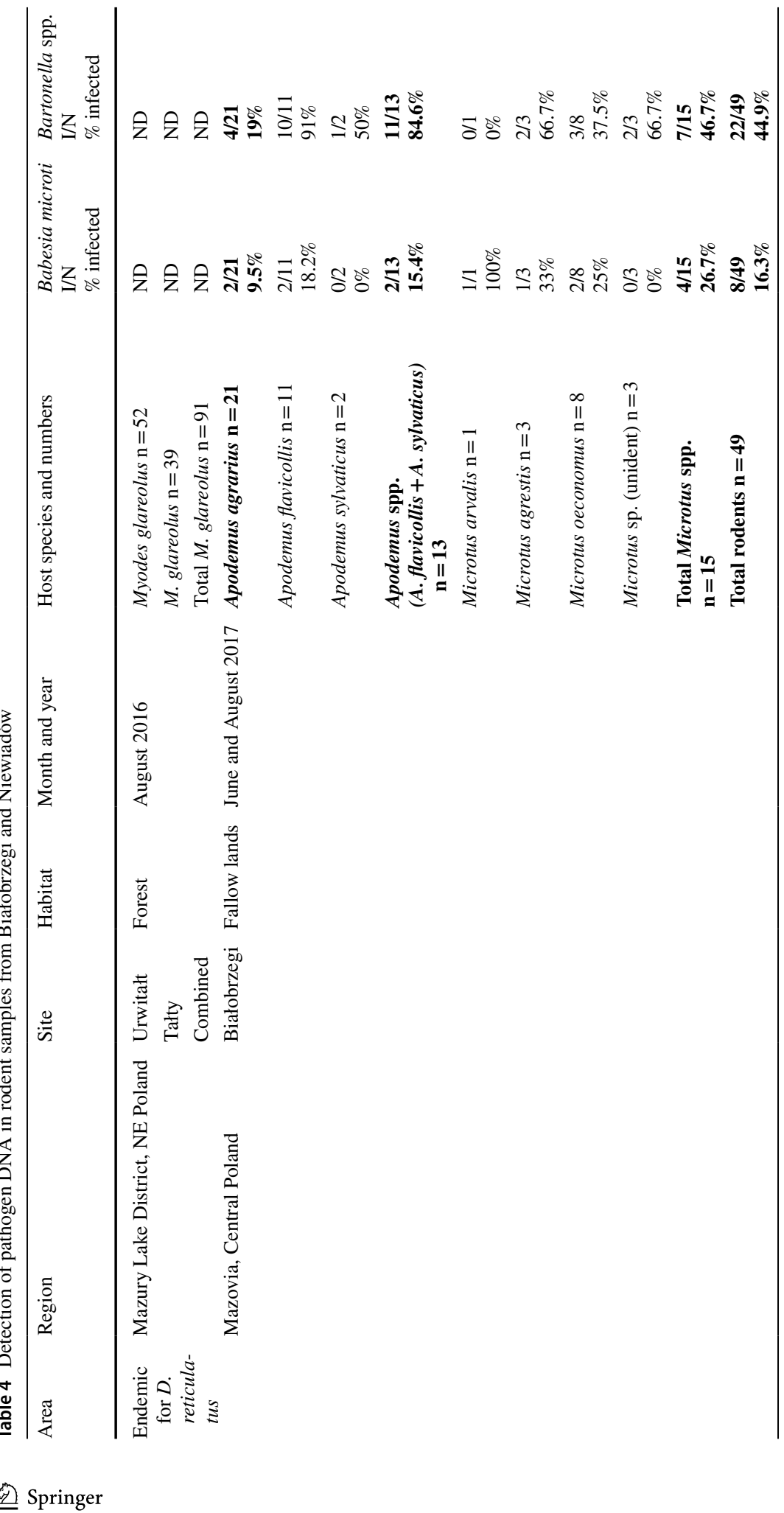




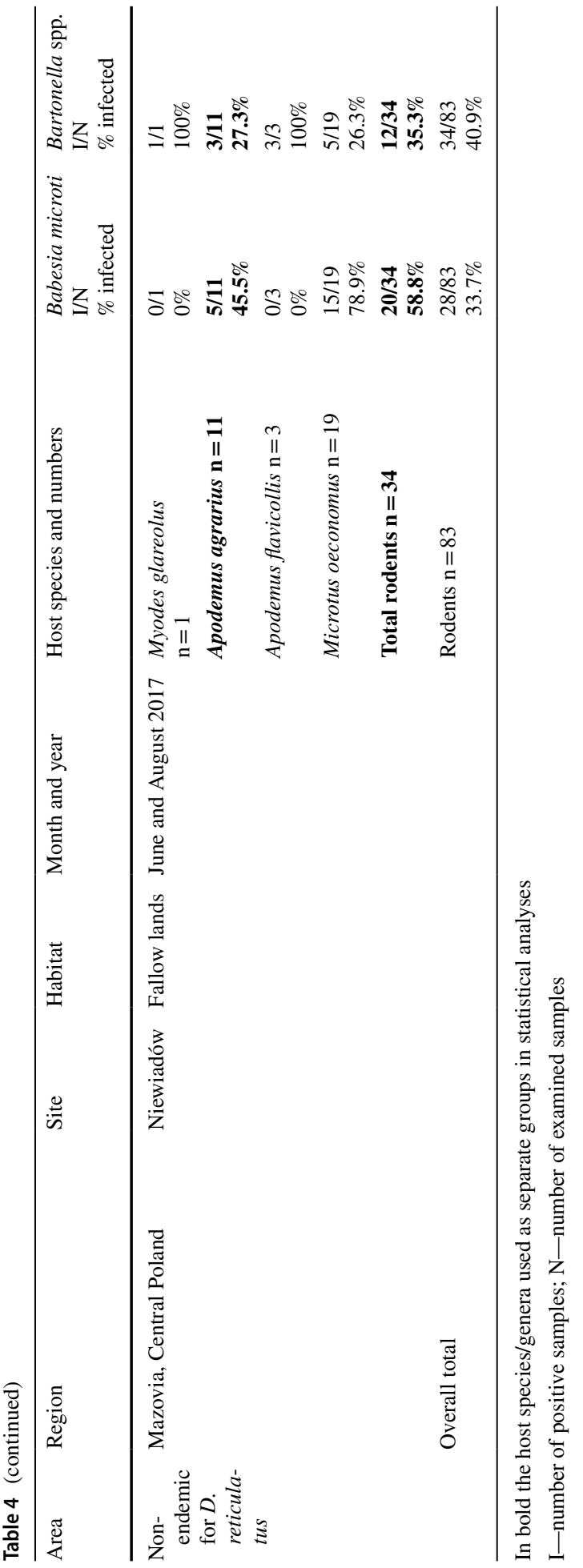


collected from Microtus spp. and the highest in ticks collected from Apodemus spp. (Rickettsia PRESENCE/ABSENCE $\times$ HOST SPECIES: $\left.\chi_{3}^{2}=33.9, \mathrm{P}<0.001\right)$. As only two ticks were positive for $B$. canis, no further analysis of this species was possible.

Host sex had significant effects on the frequency of detection of $B$. microti and Rickettsia in D. reticulatus ticks (B. microti PRESENCE/ABSENCE $\times$ HOST SEX: $\quad \chi_{1}^{2}=4.76, \quad \mathrm{P}=0.029 ; \quad$ Rickettsia PRESENCE/ABSENCE $\times$ HOST SEX: $\left.\chi_{1}^{2}=8.09, \mathrm{P}=0.004\right)$ and a similar trend was observed for Bartonella although it was not significant (Fig. 2b, NS). The frequency of PCR-positive samples was higher in both cases for ticks collected from male in comparison to female rodents.

Host age also had a significant effect on the frequency of detection of $B$. microti in $D$. reticulatus and similar trends in the same direction were noted for the detection of Bartonella and Rickettsia spp. (Fig. 2c; B. microti PRESENCE/ABSENCE $\times$ HOST AGE: $\left.\chi_{1}^{2}=3.89, \mathrm{P}=0.048\right)$. The frequency of PCR-positive samples was higher for ticks collected from adult rodents in comparison to juvenile ones.

\section{Frequency of pathogen detection in ticks from infected and non-infected rodents}

The influence of host infection status on detection of pathogen DNA in feeding ticks was analyzed for 49 rodents from Białobrzegi, for which both $D$. reticulatus ticks (Table 3 ) and the corresponding rodent host blood samples (Table 4) were available for testing for the presence of Babesia and Bartonella DNA. Comparison of the frequency of pathogen detection in ticks from infected and non-infected hosts is presented in Fig. 3a, b. Host infection had significant effect on detection of $B$. microti in ticks depending on tick stadium $(B$. microti TICK INFECTION $\times$ TICK STADIUM $\times$ rodent HOST INFECTION: $\left.\chi_{1}^{2}=14.9, \mathrm{P}<0.001\right)$. The DNA of $B$. microti was detected in $68.8 \%$ of nymphs collected from $B$. microti-positive rodents in comparison to $1.6 \%$ of nymphs collected from $B$. microti-negative rodents. However, the four B. microti-positive larvae were obtained only from uninfected hosts (Fig. 3a).

Bartonella spp. DNA was detected in $42 \%$ of nymphs and $57 \%$ of larval pools collected from Bartonella-positive rodents in comparison to $28 \%$ of nymphs and $11 \%$ of larvae collected from Bartonella-negative rodents (Bartonella TICK INFECTION $\times$ rodent HOST INFECTION: $\chi_{1}^{2}=9.09, \mathrm{P}=0.003$ ) (Fig. 3b).

The DNA of $B$. canis was detected in D. reticulatus nymphs collected from $M$. glareolus of unknown Babesia infection status and in a nymph from an uninfected M. oeconomus.

\section{Discussion}

The main finding of our study is the detection of B. canis in juvenile D. reticulatus, collected from voles that do not carry $B$. canis, hence supporting the occurrence of vertical transmission of the piroplasm under natural conditions. Additionally, through comparison of the frequency of successful pathogen detection in ticks and rodents (tick hosts) we have demonstrated clearly that the application of molecular techniques in this study has enabled detection of 'meal contamination' in ticks and that such contamination must be taken into account when evaluating the role of ticks as vectors of parasitic organisms.

To the best of our knowledge, this is the first field study in which B. canis has been detected in naturally infected juvenile $D$. reticulatus ticks. Recently, we have demonstrated transovarial transmission of $B$. canis from infected females to eggs and larvae under 

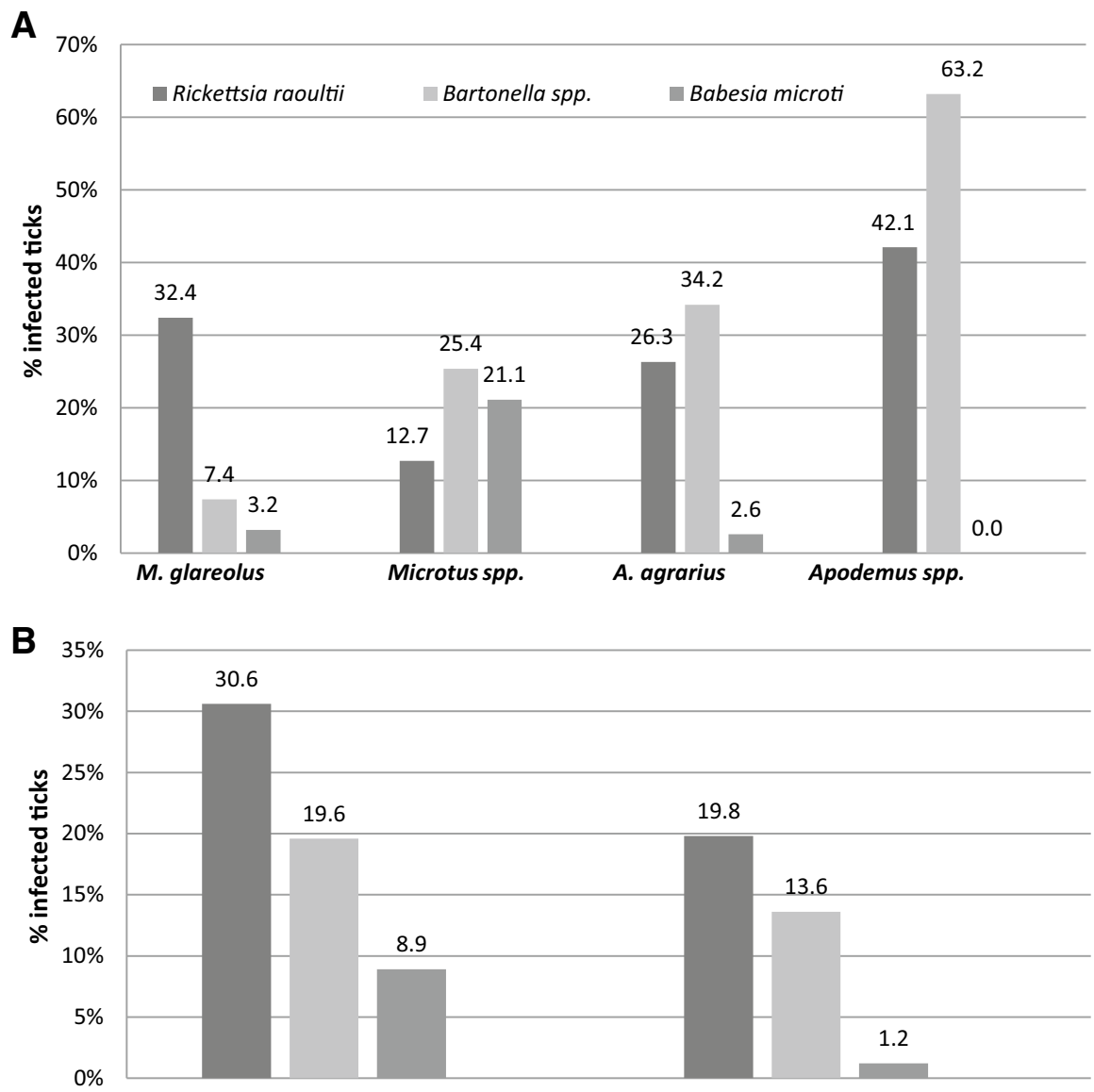

Males

Females

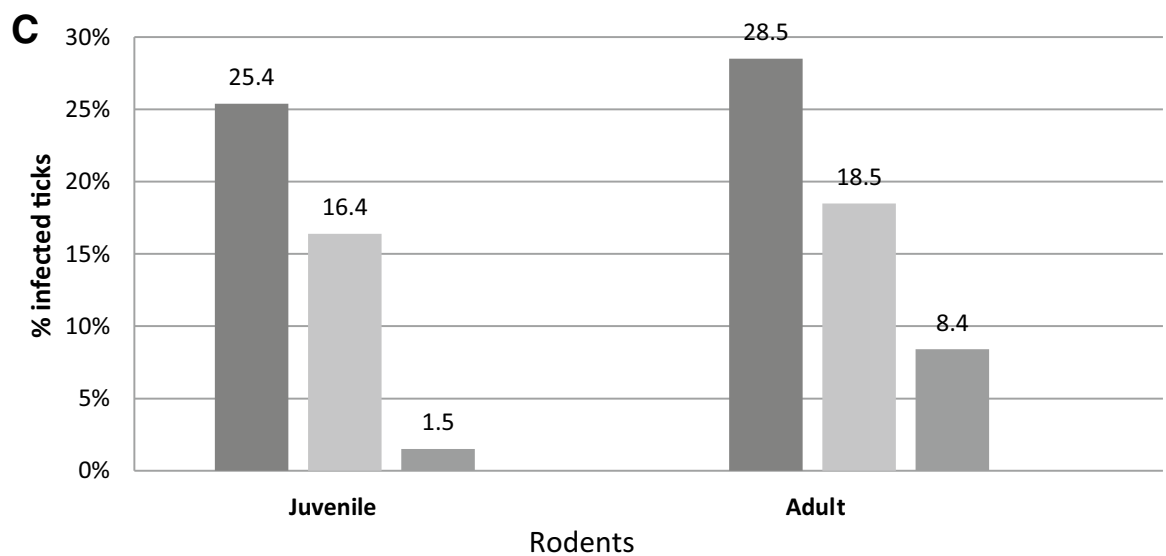

Fig. 2 Influence of host factors (a host species/genus; b host sex; $\mathbf{c}$ host age) on the frequency of pathogen detection in feeding ticks 
laboratory conditions (Mierzejewska et al. 2018). However, these studies on nidicolous juvenile $D$. reticulatus ticks were not carried out under natural conditions. In our previous study on D. reticulatus collected from rodents we found only B. microti DNA (WelcFaleciak et al. 2008b). In agreement with this earlier finding, here also the majority of Babesia-positive samples were shown to be $B$. microti. Interestingly, we have demonstrated also that rodent host factors (host species, age and infection status) have a significant effect on the frequency of detection of $B$. microti in ticks. Moreover, in agreement with previous findings (Pawelczyk et al. 2004; Welc-Faleciak et al. 2008b; Tołkacz et al. 2017) we have provided evidence that Microtus spp. constitute the main reservoir hosts of B. microti and are the major source of tick contamination with B. microti DNA.

If $D$. reticulatus constitutes a competent vector of $B$. microti, the frequency of DNA detection should be independent of rodent host factors, and should not correspond with the known effects of host species, age or sex on the prevalence of this pathogen in rodents (Pawelczyk et al. 2004; Tołkacz et al. 2017). Although it is widely accepted that D. reticulatus ticks are the main vectors of $B$. canis (notably by the link between the appearance of new canine babesiosis foci and the concurrent appearance of $D$. reticulatus in the same local environment; Matjila et al. 2005; Beelitz et al. 2012; Schaarschmidt et al. 2013; Medlock et al. 2017; de Marco et al. 2017), there are only a few papers reporting various rates of $B$. microti-positive questing adult $D$. reticulatus (Mierzejewska et al. 2015a; WójcikFatla et al. 2015; Zając et al. 2017). Since we detected the DNA of B. microti in engorged nymphs, it seems reasonable to assume that a remnant of this B. microti DNA from this nymphal meal could be detectable later in questing adults. Blood residues are present in the gut of adult ticks after molting and are regularly used for the synthesis of adipose tissue (Sonenshine and Roe 2013). A role for D. reticulatus as an important vector for B. microti appears therefore to be questionable; especially as in this study we recorded the highest prevalence of $B$. microti in $M$. oeconomus from Niewiadów, where no feeding juvenile or questing $D$. reticulatus adult ticks have been found in recent years (Mierzejewska et al. 2016). In addition, in our recent study on Microtus spp. we found vertical transmission of B. microti in voles (from females to embryos and neonates or newborns), to be a common occurrence resulting in a high prevalence of infection in new generations without a contribution from arthropod vectors (Tołkacz et al. 2017). A similar recent study in Peromyscus leucopus (Tufts and Diuk-Wasser 2018) reached much the same conclusion.

Questing adult D. reticulatus ticks from the same geographical areas in Masuria and Mazovia as those sampled in the present study have shown a prevalence of $B$. canis DNA of $2.3 \%$ and $8.0 \%$ respectively, but $B$. microti DNA was found only in 1 adult tick from Masuria (0.2\%; Mierzejewska et al. 2015a). Thus in conclusion, although we found a much higher rate of $B$. microti-positive than $B$. canis-positive juvenile D. reticulatus, we support a vector role of this tick species only for B. canis. Babesia microti detection was highly dependent on infections in rodents and hence more likely to be contamination from the infected rodents, rather than stages developing from earlier acquisition and involved in transmission.

The role of different tick species as vectors for Bartonella is still a hot topic in the scientific literature, with approximately equal numbers of scientists/papers supporting and rejecting a pivotal role for ticks as vectors (Angelakis et al. 2010; Telford and Wormser 2010; Billeter et al. 2008, 2012). There are numerous papers reporting various frequencies for the detection of Bartonella DNA in ticks (Angelakis et al. 2010; Bonnet et al. 2013; Maggi et al. 2018), including both Bartonella species typically encountered in rodents and Bartonella species of public health significance, such as B. henselae (Maggi et al. 2018; Földvári et al. 2016; Reye et al. 2013; Rar et al. 2005b). Despite these studies there are still 


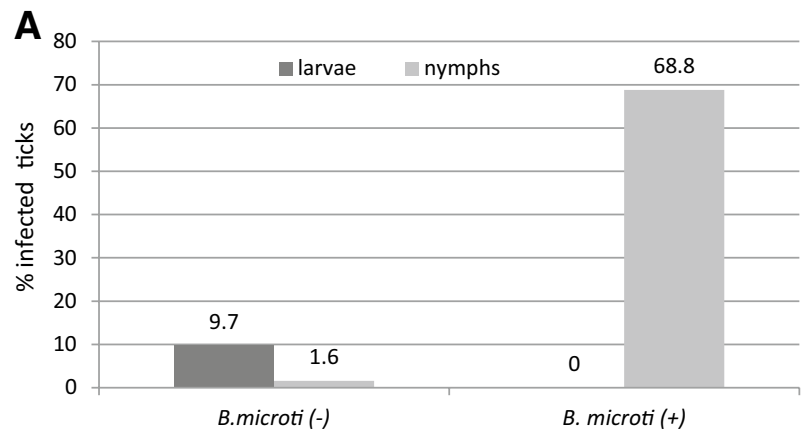

Host infection status

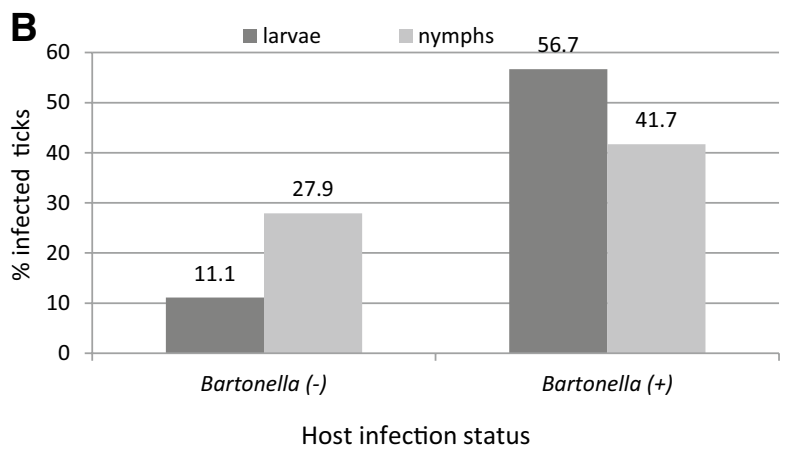

Fig. 3 Influence of host infection on the frequency of pathogen detection in feeding ticks. a For Babesia microti. b For Bartonella spp.

no unequivocally convincing experimental or epidemiological studies providing conclusive evidence that bartonellae are transmitted by ticks (Telford and Wormser 2010). Apparently, there is a weak association, or more often no association, between 'tick factors' (tick seasonality, tick foci, occurrence of borreliosis) and the occurrence of bartonellosis or seroconversion in humans (Telford and Wormser 2010; Zając et al. 2015; Muller et al. 2016). The majority of published findings on the detection of Bartonella in ticks is based on DNA detection (not on bacterial cultures) and these mostly report low prevalence $(0.5-9 \%)$ in questing hard ticks, including D. reticulatus (Bonnet et al. 2013; Reye et al. 2013; Muller et al. 2016; Maggi et al. 2018). Such low prevalence of about $0.5-1 \%$ is not compatible with a key role for ticks of this species as vectors and should be interpreted more as accidental findings, without a crucial role in epidemiology. In our study on engorged $D$. reticulatus ticks, as for $B$. microti, the frequency of detection of Bartonella DNA was significant (18\%) but also influenced by host factors, especially host species and infection status, and was the highest for ticks removed from the well-known Bartonella reservoir hostsApodemus spp. (Gutierrez et al. 2015; Paziewska et al. 2011), in which the prevalence of Bartonella infection was as high as $90 \%$. Interestingly, in our previous study on Bartonella in $D$. reticulatus (feeding juvenile and questing adults) collected in Masuria, no positive ticks were recorded (Welc-Faleciak 2008), as also in a study in Hungary (Sréter-Lancz et al. 2006) and another in Serbia (Tomanovic et al. 2013). Again, Bartonella infections were prevalent in rodent hosts from Niewiadów, where no D. reticulatus were recorded. 
Finally, all three species/genotypes of Bartonella identified in the present study have been previously found/described in rodents (Welc-Faleciak et al. 2008a; Paziewska et al. 2011; Buffet et al. 2013; Gutierrez et al. 2015; Tołkacz et al. 2018). Thus we conclude that the Bartonella DNA detected in feeding juvenile $D$. reticulatus in this study represents a case of typical 'meal contamination' and does not support a vector role of this tick species for these bacteria.

Rickettsia was the most common pathogen detected in juvenile D. reticulatus in this study and this high prevalence corresponds well with the high prevalence noted in questing adult $D$. reticulatus in Poland in our previous study (Mierzejewska et al. 2015a). All sequenced PCR products contained $R$. raoultii, which is also the most common bacterium (endosymbiont; Alberdi et al. 2012) found in D. reticulatus (Stańczak 2006; Silaghi et al. 2011; Tijsse-Klasen et al. 2013; Zając et al. 2017) and is transmitted vertically by the tick (Samoylenko et al. 2009). Interestingly, we found a significant influence of host species on the prevalence of Rickettsia in ticks, but in this case it might have been dependent more on the content of tick samples, especially on the number of larvae in pools rather than on host factors, as no rodent species are recognized as $R$. raoultii reservoirs. Another reason may be the natural dynamics of tick microbiota in relation to feeding status. A growing number of studies on the microbiome of ticks indicate high dynamic fluctuations/changes of microorganisms of different taxa in the course of the consecutive developmental and reproductive stages during the life-cycle of ticks (hatching, questing, feeding, molting, sperm or egg development) (Menchaca et al. 2013). It has been shown that some microorganisms are undetectable at times, even by molecular tools, depending on the tick's developmental stadium and that a blood meal can promote or inhibit the growth of some taxa, thus influencing their detection (Heise et al. 2010). Therefore, a recent uptake of blood by $D$. reticulatus larvae and nymphs may enhance the detectability of $R$. raoulti in ticks collected from rodents.

\section{Conclusions}

Vertical transmission of $B$. canis in D. reticulatus ticks was confirmed in the field. Additionally, we demonstrated that 'meal contamination' generates a confounding signal in molecular detection of pathogen DNA extracted from ticks collected from infected hosts and must be taken into account in evaluating the suitability of tick species as vectors of the respective pathogens.

Acknowledgements The study was funded by National Science Centre (NCN) Sonata Bis Grant No. 2014/14/E/NZ7/00153.

Open Access This article is distributed under the terms of the Creative Commons Attribution 4.0 International License (http://creativecommons.org/licenses/by/4.0/), which permits unrestricted use, distribution, and reproduction in any medium, provided you give appropriate credit to the original author(s) and the source, provide a link to the Creative Commons license, and indicate if changes were made.

\section{References}

Alberdi MP, Nijhof AM, Jongejan F, Bell-Sakyi L (2012) Tick cell culture isolation and growth of Rickettsia raoultii from Dutch Dermacentor reticulatus ticks. Ticks Tick Born Dis 3:349-354 
Angelakis E, Billeter SA, Breitschwerdt EB, Chomel BB, Raoult D (2010) Potential for tick-borne bartonelloses. Emerg Infect Dis 16:385-391

Bajer A, Welc-Faleciak R, Bednarska M, Alsarraf M, Behnke-Borowczyk J, Siński E et al (2014) Long-term spatiotemporal stability and dynamic changes in the haemoparasite community of bank voles (Myodes glareolus) in NE Poland. Microb Ecol 68:196-211. https://doi.org/10.1007/s00248-014-0390-9

Beelitz P, Schumacher S, Marholdt F, Pfister K, Silaghi C (2012) The prevalence of Babesia canis canis in marsh ticks (Dermacentor reticulatus) in the Saarland. Berl Munch Tierarztl Wochenschr 125:168-171

Behnke JM, Barnard CJ, Bajer A, Bray D, Dinmore J, Frake K, Osmond J, Race T, Siński E (2001) Variation in the helminth community structure in bank voles (Clethrionomys glareolus) from three comparable localities in the Mazury Lake District region of Poland. Parasitology 123:401-414

Behnke JM, Bajer A, Harris PD, Newington L, Pidgeon E, Rowlands G et al (2008a) Temporal and between-site variation in helminth communities of bank voles (Myodes glareolus) from N.E. Poland. 1. Regional fauna and component community levels. Parasitology 135:985-997

Behnke JM, Bajer A, Harris PD, Newington L, Pidgeon E, Rowlands G et al (2008b) Temporal and between-site variation in helminth communities of bank voles (Myodes glareolus) from N.E. Poland. 2. The infracommunity level. Parasitology 135:999-1018

Billeter SA, Levy MG, Chomel BB, Breitschwerdt EB (2008) Vector transmission of Bartonella species with emphasis on the potential for tick transmission. Med Vet Entomol 22:1-15

Billeter SA, Kasten RW, Killmaster LF, Breitschwerdt EB, Levin ML, Levy MG, Kosoy MY, Chomel BB (2012) Experimental infection by capillary tube feeding of Rhipicephalus sanguineus with Bartonella vinsonii subspecies berkhoffi. Comp Immunol Microbiol Infect Dis 35:9-15. https://doi.org/10.1016/j. cimid.2011.09.004

Bonnet S, Jouglin M, L'Hostis M, Chauvin A (2007a) Babesia sp. EU1 from roe deer and transmission within Ixodes ricinus. Emerg Infect Dis 13:1208-1210

Bonnet S, Jouglin M, Malandrin L, Becker C, Agoulon A, L'Hostis M et al (2007b) Transstadial and transovarial persistence of Babesia divergens DNA in Ixodes ricinus ticks fed on infected blood in a new skin-feeding technique. Parasitology 134:197-207

Bonnet S, de la Fuente J, Nicollet P, Liu X, Madani N, Blanchard B, Maingourd C, Alongi A, Torina A, Fernandez de Mera IG, Vicente J, George JC, Vayssier-Taussat M, Joncour G (2013) Prevalence of tickborne pathogens in adult Dermacentor spp. ticks from nine collection sites in France. Vector Borne Zoonotic Dis 13:226-236

Buffet JP, Pisanu B, Brisse S, Roussel S, Felix B, Halos L et al (2013) Deciphering Bartonella diversity, recombination, and host specificity in a rodent community. PLoS ONE 87:e68956

de Marco MDMF, Hernández-Triana LM, Phipps LP, Hansford K, Mitchell ES, Cull B, Swainsbury CS, Fooks AR, Medlock JM, Johnson N (2017) Emergence of Babesia canis in southern England. Parasit Vectors 10:241. https://doi.org/10.1186/s13071-017-2178-5

Egyed L, Makrai L (2014) Cultivable internal bacterial flora of ticks isolated in Hungary. Exp Appl Acarol 63:107-122

Estrada-Peña A, Bouattour A, Camicas JL, Walker AR (2004) Ticks of domestic animals in the Mediterranean region: a guide to identification of species. University of Zaragoza, Saragossa

Földvári G, Siroký P, Szekeres S, Majoros G, Sprong H (2016) Dermacentor reticulatus: a vector on the rise. Parasit Vectors 9:314

Gutierrez R, Krasnov B, Morick D, Gottlieb Y, Khokhlova IS, Harrus S (2015) Bartonella infection in rodents and their flea ectoparasites: an overview. Vector Borne Zoonotic Dis 15:27-39

Heise SR, Elshahed MS, Little SE (2010) Bacterial diversity in Amblyomma americanum (Acari: Ixodidae) with a focus on members of the genus Rickettsia. J Med Entomol 47:258-268. https://doi.org/10.1093/ jmedent/47.2.258

Karbowiak G (2009) Kleszcz ląkowy Dermacentor reticulatus—występowanie, biologa i rola jako wektora chorób odkleszczowych. Habilitation thesis. Instytut Parazytologii im. Witolda Stefańskiego PAN, Warsaw (Article in Polish)

Maggi RG, Toliver M, Richardson T, Mather T, Breitschwerdt EB (2018) Regional prevalences of Borrelia burgdorferi, Borrelia bissettiae, and Bartonella henselae in Ixodes affinis, Ixodes pacificus and Ixodes scapularis in the USA. Ticks Tick Borne Dis. https://doi.org/10.1016/j.ttbdis.2018.11.015

Matjila TP, Nijhof AM, Taoufik A, Houwers D, Teske E, Penzhorn BL et al (2005) Autochthonous canine babesiosis in the Netherlands. Vet Parasitol 131:23-29. https://doi.org/10.1016/j.vetpar.2005.04.020

Medlock JM, Hansford KM, Vaux AGC, Cull B, Abdullah S, Pietzsch ME, Wall R, Johnson N, Phipps LP (2017) Distribution of the tick Dermacentor reticulatus in the United Kingdom. Med Vet Entomol 31:281-288. https://doi.org/10.1111/mve.12235 
Menchaca AC, Visi DK, Strey OF, Teel PD, Kalinowski K, Allen MS, Williamson PC (2013) Preliminary assessment of microbiome changes following blood-feeding and survivorship in the Amblyomma americanum nymph-to-adult transition using semiconductor sequencing. PLoS ONE 8:e67129

Mierzejewska EJ, Pawełczyk A, Radkowski M, Welc-Falęciak R, Bajer A (2015a) Pathogens vectored by the tick, Dermacentor reticulatus, in endemic regions and zones of expansion in Poland. Parasit Vectors 8:490

Mierzejewska EJ, Welc-Falęciak R, Karbowiak G, Kowalec M, Behnke JM, Bajer A (2015b) Dominance of Dermacentor reticulatus over Ixodes ricinus (Ixodidae) on livestock, companion animals and wild ruminants in eastern and central Poland. Exp Appl Acarol 66:83-101

Mierzejewska EJ, Estrada-Peña A, Alsarraf M, Kowalec M, Bajer A (2016) Mapping of Dermacentor reticulatus expansion in Poland in 2012-2014. Ticks Tick Borne Dis 7:94-106

Mierzejewska EJ, Dwużnik D, Bajer A (2018) Molecular study of transovarial transmission of Babesia canis in the Dermacentor reticulatus tick. Ann Agric Environ Med 25:669-671. https://doi. org/10.26444/aaem/94673

Müller A, Reiter M, Schötta AM, Stockinger H, Stanek G (2016) Detection of Bartonella spp. in Ixodes ricinus ticks and Bartonella seroprevalence in human populations. Ticks Tick Borne Dis 7:763-767

Pawełczyk A, Bajer A, Behnke JM, Gilbert FS, Siński E (2004) Factors affecting the component community structure of haemoparasites in common voles (Microtus arvalis) from the Mazury Lake District region of Poland. Parasitol Res 92:270-284

Paziewska A, Harris PD, Zwolinska L, Bajer A, Siński E (2011) Recombination within and between species of the alpha proteobacterium Bartonella infecting rodents. Microb Ecol 61:134-145

Pichon B, Egan D, Rogers M, Gray J (2003) Detection and identification of pathogens and host DNA in unfed host-seeking Ixodes ricinus L. (Acari: Ixodidae). J Med Entomol 40:723-731

Rar VA, Maksimova TG, Zakharenko LP, Bolykhina SA, Dobrotvorsky AK, Morozova OV (2005a) Babesia DNA detection in canine blood and Dermacentor reticulatus ticks in southwestern Siberia, Russia. Vector Borne Zoonotic Dis 5:285-287

Rar VA, Fomenko NV, Dobrotvorsky AK, Livanova NN, Rudakova SA, Fedorov EG, Astanin VB, Morozova OV (2005b) Tickborne pathogen detection, Western Siberia, Russia. Emerg Infect Dis 11:1708-1715

Reye AL, Stegniy V, Mishaeva NP, Velhin S, Hubschen JM, Ignatyev G, Muller CP (2013) Prevalence of tick-borne pathogens in Ixodes ricinus and Dermacentor reticulatus ticks from different geographical locations in Belarus. PLoS ONE 8:e54476

Roux V, Rydkina E, Eremeeva M, Raoult D (1997) Citrate synthase gene comparison, a new tool for phylogenetic analysis, and its application for the rickettsiae. Int J Syst Bacteriol 47:252-261. https ://doi.org/10.1099/00207713-47-2-252

Rubel F, Brugger K, Pfeffer M, Chitimia-Dobler L, Didyk YM, Leverenz S, Dautel H, Kahl O (2016) Geographical distribution of Dermacentor marginatus and Dermacentor reticulatus in Europe. Ticks Tick Borne Dis 7:224-233

Samoylenko I, Shpynov S, Raoult D, Rudakov N, Fournier PE (2009) Evaluation of Dermacentor species naturally infected with Rickettsia raoultii. Clin Microbiol Infect 2:305-306. https://doi.org/10. $1111 /$ j.1469-0691.2008.02249

Schaarschmidt D, Gilli U, Gottstein B, Marreros N, Kuhnert P, Daeppen JA et al (2013) Questing Dermacentor reticulatus harbouring Babesia canis DNA associated with outbreaks of canine babesiosis in the Swiss Midlands. Ticks Tick Borne Dis 4:334-340. https://doi.org/10.1016/j.ttbdi s.2013.01.007

Silaghi C, Hamel D, Thiel C, Pfister K, Pfeffer M (2011) Spotted fever group rickettsiae in ticks, Germany. Emerg Infect Dis 17:890-892. https://doi.org/10.3201/eid1705.101445

Siuda K (1993) Kleszcze Polski (Acari: Ixodida): Systematyka i rozmieszczenie. Warszawa, Polskie Towarzystwo Parazytologiczne

Sonenshine DE, Roe RM (2013) Biology of ticks (vol 1), 2nd edn. Oxford University Press, New York

Sréter-Lancz Z, Tornyai K, Széll Z, Sréter T, Márialigeti K (2006) Bartonella infections in fleas (Siphonaptera: Pulicidae) and lack of bartonellae in ticks (Acari: Ixodidae) from Hungary. Folia Parasitol (Praha) 53:313-316

Stańczak J (2006) Detection of spotted fever group (SFG) rickettsiae in Dermacentor reticulatus (Acari: Ixodidae) in Poland. Int J Med Microbiol 296:144-148. https://doi.org/10.1016/j.ijmm.2006.01.014

Telford SR III, Wormser GP (2010) Bartonella spp. transmission by ticks not established. Emerg Infect Dis 16:379-384

Tijsse-Klasen E, Hansford KM, Jahfari S, Phipps P, Sprong H, Medlock JM (2013) Spotted fever group rickettsiae in Dermacentor reticulatus and Haemaphysalis punctata ticks in the UK. Parasit Vectors 19:212. https://doi.org/10.1186/1756-3305-6-212 
Tołkacz K, Bednarska M, Alsarraf M, Dwużnik D, Grzybek M, Welc-Falęciak R et al (2017) Prevalence, genetic identity and vertical transmission of Babesia microti in three naturally infected species of vole, Microtus spp. (Cricetidae). Parasit Vectors 10(1):66. https://doi.org/10.1186/s1307 1-017-2007-x

Tołkacz K, Alsarraf M, Kowalec M, Dwużnik D, Grzybek M, Gabral J, Behnke JM, Bajer A (2018) Bartonella infections in three species of Microtus: prevalence and genetic diversity, vertical transmission and the effect of concurrent Babesia microti infection on its success. Parasit Vectors 11:491. https:// doi.org/10.1186/s13071-018-3047-6

Tomanovic S, Chochlakis D, Radulovic Z, Milutinovic M, Cakic S, Mihaljica D, Tselentis Y, Psaroulaki A (2013) Analysis of pathogen co-occurrence in host-seeking adult hard ticks from Serbia. Exp Appl Acarol 59:367-376

Tufts DM, Diuk-Wasser MA (2018) Transplacental transmission of tick-borne Babesia microti in its natural host Peromyscus leucopus. Parasit Vectors 11:286. https://doi.org/10.1186/s13071-018-2875-8

Welc-Falęciak 2008 Pasożyty krwi gryzoni Babesia microti i Bartonella spp. patogenne dla człowieka: badania środowiskowe i molekularne. PhD thesis. Uniwersytet Warszawski (in Polish)

Welc-Falęciak R, Paziewska A, Bajer A, Behnke JM, Siński E (2008a) Bartonella spp. infection in rodents from different habitats in the Mazury Lake District, Northeast Poland. Vector Borne Zoonotic Dis 8:467-474

Welc-Falęciak R, Bajer A, Behnke JM, Siński E (2008b) Effects of host diversity and the community composition of ixodid ticks (Ixodidae) on Babesia microti infection. Int J Med Microbiol 296:137-143. https://doi.org/10.1016/j.ijmm.2007.12.002

Wodecka B, Skotarczak B (2016) Identification of host blood-meal sources and Borrelia in field-collected Ixodes ricinus ticks in north-western Poland. Ann Agric Environ Med 23:59-63. https://doi. org/10.5604/12321966.1196853

Wójcik-Fatla A, Zając V, Sawczyn A, Cisak E, Dutkiewicz J (2015) Babesia spp. in questing ticks from eastern Poland: prevalence and species diversity. Parasit Res 114:3111-3116

Zając V, Wójcik-Fatla A, Dutkiewicz J, Szymańska J (2015) Bartonella henselae in eastern Poland: the relationship between tick infection rates and the serological response of individuals occupationally exposed to tick bites. J Vector Ecol 40:75-82. https://doi.org/10.1111/jvec.12135

Zając V, Wójcik-Fatla A, Sawczyn A, Cisak E, Sroka J, Kloc A, Zając Z, Buczek A, Dutkiewicz J, Bartosik K (2017) Prevalence of infections and co-infections with 6 pathogens in Dermacentor reticulatus ticks collected in eastern Poland. Ann Agric Environ Med 21:26-32

Publisher's Note Springer Nature remains neutral with regard to jurisdictional claims in published maps and institutional affiliations.

\section{Affiliations}

\section{Dorota Dwużnik ${ }^{1}$ Ewa J. Mierzejewska' ${ }^{1}$ Paulina Drabik ${ }^{1}$. Agnieszka Kloch ${ }^{2}$. Mohammed Alsarraf ${ }^{1} \cdot$ Jerzy M. Behnke ${ }^{3}$. Anna Bajer ${ }^{1}$ (I)}

Anna Bajer

anabena@biol.uw.edu.pl

Dorota Dwużnik

dorota.dwuznik@biol.uw.edu.pl

Ewa J. Mierzejewska

ewajuliamierzejewska@gmail.com

Paulina Drabik

paulina.drabik@student.uw.edu.pl

Agnieszka Kloch

a.kloch@biol.uw.edu.pl

Mohammed Alsarraf

muha@biol.uw.edu.pl 
Jerzy M. Behnke

jerzy.behnke@nottingham.ac.uk

1 Department of Parasitology, Faculty of Biology, University of Warsaw, Warsaw, Poland

2 Department of Ecology, Faculty of Biology, Biological and Chemical Research Centre, University of Warsaw, ul. Żwirki i Wigury 101, 02-089 Warsaw, Poland

3 School of Life Sciences, University of Nottingham, University Park, Nottingham NG7 2RD, UK 